\title{
PERAN AKUNTANSI KARBON PADA PERUSAHAAN DALAM PENCEGAHAN GLOBAL WARMING
}

\author{
Ayuni Rahmawati ${ }^{1}$; Indah Tsamrotussaadah ${ }^{2}$; Zahrah Salsabila ${ }^{3}$; \\ Agus Maulana ${ }^{4}$ \\ Universitas Pembangunan Nasional Veteran Jakarta \\ ayunirahma21@gmail.com¹, indahtsam@gmail.com², salsabila.2067@gmail.com³, \\ agus.maulana@upnvj.ac.id ${ }^{4}$ \\ http://dx.doi.org/10.21460/jrak.2021.172.399
}

\begin{abstract}
ABSTRAK
Pada tahun 2018-2019 tingkat deforestasi Indonesia mengalami peningkatan dari tahun sebelumnya. Salah satu penyebab terjadinya ialah hilangnya sebagian fungsi hutan sebagai penyerap karbon akibat penebangan hutan yang sebagian dilakukan untuk kepentingan perusahaan. Hal ini mempengaruhi perubahan iklim yang menyebabkan terjadinya pemanasan global. Sehingga, muncullah akuntansi karbon yang bertujuan untuk menghitung jumlah emisi karbon yang dihasilkan oleh perusahaan setiap tahunnya. Metodologi penelitian ini menggunakan metode penelitian kualitatif kajian pustaka yang bersumber pada buku-buku teks, website resmi di internet, hasil penelitian dalam bentuk skripsi, dan jurnal-jurnal ilmiah. Adapun tujuan penulis melakukan penelitian ini ialah untuk mengetahui peran akuntansi karbon pada perusahaan dalam pencegahan global warming. Hasil penelitian ini menunjukkan bahwa akuntansi karbon berperan untuk membantu perluasan daerah penyerapan gas rumah kaca (GRK) dan juga membantu para pemegang kepentingan perusahaan untuk mengatur strategi agar emisi karbon yang dihasilkan dapat diminimalisasi. Selain itu, akuntansi karbon juga dapat memberikan banyak manfaat bagi lingkungan sekitarnya. Jadi, dengan diterapkannya akuntansi karbon di perusahaan dapat memperluas lahan penyerapan GRK. Dengan begitu, akuntansi karbon akan membantu global warming untuk tidak semakin memburuk atau bahkan dapat menurunkannya.
\end{abstract}

Kata Kunci: akuntansi karbon, pemanasan global, peran akuntansi karbon, gas rumah kaca, emisi karbon

\section{ABSTRACT}

In 2018-2019 the rate of deforestation in Indonesia has increased from the previous year. One of the causes of the increase in deforestation is the loss of part of the forest's function as a carbon sink due to deforestation, partly for the benefit of companies. This affects climate change which causes global warming. Therefore, carbon accounting emerged, which aims to calculate the amount of carbon emissions produced by companies every year. This research methodology uses qualitative research methods literature review sourced from text books, the official website of the internet, research results in the form of a thesis, and scientific journals. The purpose of this research is to determine the role of carbon accounting in companies in preventing global warming. The results of this study indicate that carbon accounting plays a role to expand the absorption area of greenhouse gases and also to help corporate stakeholders to set strategies so that the resulting carbon emissions can be minimized. In addition, carbon accounting can also provide many benefits to the surrounding environment. That way, carbon accounting will help global warming not get worse or even reduce the level of global warming.

Keywords: carbon accounting, global warming, the role of carbon accounting, greenhouse gases, carbon emission 


\section{PENDAHULUAN}

Indonesia terkenal dengan kekayaan sumber daya alamnya, mulai dari lautan, minyak bumi, gas alam, batu bara, dan hutan. Bersumber pada data Direktorat Jenderal Planologi Kehutanan dan Tata Lingkungan (PKTL) Kementrian Lingkungan Hidup dan Kehutanan (KLHK) didapatkan hasil pemantauan bahwa luas lahan berhutan seluruh daratan Indonesia pada tahun 2019 adalah 94,1 juta ha atau setara dengan 50,1\% dari total daratan Indonesia (PPID, 2020). Menurut Taurisianti dan Kurniawati (2016) hutan Indonesia dapat menyerap karbon yang dihasilkan oleh Indonesia sendiri ataupun karbon dari Negara lain. Sehingga Indonesia disebut sebagai paru-paru dunia. Namun demikian, PPID (2020) menyatakan bahwa terjadi deforestasi atau yang dapat diartikan sebagai proses penghilangan hutan akibat ulah manusia. Pada tahun 2018-2019 terjadi deforestasi sebesar 462,4 ribu ha. Sedangkan pada tahun 2017-2018 terjadi deforestasi sebesar 439,4 ribu ha, sehingga dapat disimpulkan bahwa terjadi peningkatan deforestasi sebesar 23 ribu ha. Salah satu penyebab peningkatan deforestasi ialah penebangan hutan yang dilakukan untuk kepentingan perusahaan. Peningkatan deforestasi menjadi hal yang penting karena potensi utama hutan ialah menyerap karbon.

Hilangnya sebagian fungsi hutan sebagai penyerap karbon mempengaruhi perubahan iklim yang menyebabkan terjadinya pemanasan global atau global warming baik di Indonesia maupun dunia. Pemanasan global yang terus meningkat menyebabkan iklim menjadi tidak menentu dan berubah-ubah. Hal ini menyebabkan timbulnya berbagai bencana alam. Oleh karena itu, beberapa negara di dunia pada tahun 1997 berkumpul untuk menandatangani Protokol Kyoto yang ditindaklanjuti oleh penandatanganan Bali Roadmap yang diselenggarakan pada tahun 2007 atas bentuk keseriusan negara-negara tersebut dalam mengatasi global warming (United Nations Climate Change, 2012). Selain adanya Protokol Kyoto dan Bali Roadmap, pada tahun 2016 juga diselenggarakan Conference of the Parties (COP 21) yang menghasilkan sebuah perjanjian yaitu Paris Agreement dengan tujuan untuk mencegah peningkatan pemanasan global (Zuhrufiyah and Anggraeni, 2019).

Berdasarkan penelitian sebelumnya oleh Andriyani (2010), dikatakan bahwa proses bisnis oleh perusahaan menimbulkan dampak negatif bagi lingkungan sekitar dan tentu juga dirasakan oleh dunia. Salah satu dampak negatif tersebut adalah global warming. Masalah global warming ini menjadi faktor berbagai pihak agar dapat lebih bertanggung jawab terhadap banyaknya emisi yang dikeluarkan pada setiap proses bisnis yang dilakukan yang berdampak kepada lingkungan sekitar. Maka dari itu, beberapa perusahaan mulai menerapkan akuntansi lingkungan yang mencatat setiap biaya lingkungan seperti biaya pencegahan, biaya pendeteksian, biaya kegagalan internal, dan biaya kegagalan eksternal yang ditimbulkan oleh perusahaan. Namun, hadirnya akuntansi lingkungan dirasa kurang cukup karena belum dapat menggambarkan secara keseluruhan sistem perhitungan dampak negatif yang tepat bagi lingkungan. Maka dari itu, muncullah akuntansi karbon sebagai upaya pengukuran jumlah karbondioksida di atmosfer yang merupakan dampak negatif dari proses bisnis. Hal ini tentu membawa dampak positif bagi lingkungan karena bersumber dari penelitian sebelumnya oleh Martusa (2009), sebelum adanya akuntansi karbon perusahaan hanya berorientasi pada penghasilan tanpa memikirkan lingkungan sekitar.

Pada penelitian sebelumnya oleh Dwijayanti (2011) dibuktikan bahwa penerapan carbon accounting membawa manfaat yang baik bagi perusahaan maupun lingkungan sekitar. Dengan menerapkan akuntansi karbon pada industri-industri maka tingkat polusi udara dan GRK yang merupakan bagian dari faktor pemanasan global akan berkurang. Selain itu, melalui penerapan akuntansi karbon maka lahan penyerapan gas rumah kaca menjadi lebih luas karena adanya pemulihan hutan-hutan gundul (rusak). Jika lahan penyerapan gas rumah kaca menjadi lebih luas maka potensi terjadinya bencana alam dapat dikurangi. Selain itu, akuntansi karbon juga memiliki manfaat untuk menambah nilai perusahaan, seperti yang disebutkan dalam penelitian Kelvin et al. (2017) bahwa pengungkapan emisi karbon 
dapat menarik perhatian investor karena disebutkan dalam penelitian Choi et al. dalam Kelvin et al. (2017) apabila suatu perusahaan mengungkap emisi karbon di dalam laporan keuangannya maka hal tersebut telah menunujukkan keseriusan perusahaan terhadap masalah pemanasan global akibat GRK. Kenaikan nilai perusahaan tervisualisasi dari tingginya nilai saham perusahaan. Perbedaan penelitian ini dengan penelitian sebelumnya adalah terletak pada metode dan lingkup penelitiannya. Penelitian ini menggunakan studi literatur secara mendalam sesuai dengan perkembangan akutansi karbon saat ini dengan ruang lingkup yang berfokus di negara Indonesia. Adapun kontribusi dari penelitian ini adalah menyediakan literatur pendukung dalam bahasan akuntansi karbon yang berfokus pada latar belakang, peran akuntansi karbon, dan bagaimana praktik pengukuran, pencatatan, penyajian, dan pengungkapan dan pelaporan akuntansi karbon di Indonesia.

Berdasarkan uraian tersebut, maka tujuan dilakukan penelitian ini ialah untuk mengetahui seberapa besar peran akuntansi karbon terhadap pencegahan pemanasan global. Dengan adanya hasil penelitian sebelumnya maka penelitian ini dilakukan untuk memperkuat bukti bahwa akuntansi karbon sangat diperlukan untuk diterapkan pada industri-industri di Indonesia demi pencegahan pemanasan global.

\section{KAJIAN LITERATUR}

\section{Akuntansi Karbon (Carbon Accounting)}

Menurut Taurisianti \& Kurniawati (2016) carbon accounting memiliki beberapa teori yang mendasari, salah satunya yaitu: akuntansi karbon adalah proses ketika organisasi menghitung dan melaporkan emisi gas rumah kaca mereka. Sehingga dapat disimpulkan bahwa akuntansi karbon adalah pencatatan laporan keuangan mengenai emiten karbon yang dihasilkan perusahaan. Dengan adanya pencatatan ini maka perusahaan dapat menghitung tingkat emisi karbon yang didapatkan dari proses pengukuran. Sehingga manajer perusahaan dapat menentukan strategi-strategi yang tepat untuk meminimalisasi jumlah emisi karbon yang dihasilkan pada periode selanjutnya serta melaporkannya

kepada

stakeholders perusahaan.

Carbon accounting semakin diperkuat dengan adanya penandatanganan Protokol Kyoto oleh segenap negara sebagai bentuk persetujuan internasional mengenai global warming. Negara-negara yang menandatangani protokol ini berjanji bertanggung jawab dalam meminimalisasi jumlah emisi karbon yang akan mereka hasilkan nantinya (Taurisianti \& Kurniawati, 2014).

Berdasarkan penelitian Setyaningrum (2015), Protokol Kyoto mengatur tiga mekanisme fleksibel, yaitu:

1. Implementasi Bersama (Joint Implementation)

Implementasi Bersama yaitu proses pengurangan emisi dimana negara-negara maju (Annex I) dapat mengalihkan pengurangan emisi karbon dengan melakukan proyek kerjasama antarnegara dengan tujuan pengurangan emisi karbon.

2. Perdagangan Emisi (Emission Trading) Perdagangan Emisi adalah sebuah mekanisme jual-beli emisi antarnegara industri. Negara industri dengan emisi gas rumah kacanya di bawah batas yang diperbolehkan dapat memasarkan jatah lebih emisi yang dimilikinya kepada negara industri lain yang tidak mampu menyelesaikan kewajibannya. Akan tetapi, jumlah emisi gas rumah kaca yang dipasarkan dibatasi supaya pembeli emisi tetap menyelesaikan kewajibannya.

3. Mekanisme Pembangunan Bersih (Clean Development Mechanism)

Mekanisme Pembangunan Bersih ialah mekanisme yang diharapkan dapat membantu negara maju (Annex I) dalam menyelesaikan target pengurangan emisi karbon dan negara berkembang (non Annex I) dapat mengimplementasikan program pembangunan berkelanjutan. Hal ini dapat dilakukan negara maju dengan cara berinvestasi pada program pengurangan emisi atau program lainnya yang memiliki potensi untuk meminimalisasi emisi atau menyerap gas rumah kaca di negara berkembang (non Annex I). Kemudian, hasilnya akan dicatat sebagai pengurangan emisi karbon di negara maju (Annex I) yang berinvestasi. 
Pada Negara Indonesia sendiri, mekanisme Protokol Kyoto dilaksanakan melalui penetapan Undang-Undang Nasional Indonesia Nomor 32 Tahun 2009. UndangUndang ini ialah bentuk implementasi Protokol Kyoto yang berisi tentang perlindungan dan pengelolaan lingkungan hidup (Setyaningrum, 2015).

Kemudian pada beberapa negara maju pun telah menerapkan carbon accounting, seperti pada tahun 2016, United Nations Climate Change Conference (UNFCCC) dalam Conference of the Parties 21 (COP 21) yang berdasarkan penelitian Seo, S. Niggol (2017) dilaksanakan di Paris menghasilkan perjanjian terbaru yaitu Paris Agreement. Paris Agreement ditetapkan dalam rangka menangani mitigasi, pembiayaan, dan adaptasi emisi gas rumah kaca yang dimulai pada tahun 2020. Tujuan dari perjanjian ini adalah untuk mencegah terjadinya peningkatan suhu global. Perjanjian ini mulai berlaku sejak tanggal 4 November 2016, kemudian pada tanggal 19 Mei 2017, sebanyak 195 negara bagian dan Uni Eropa ikut serta dalam menandatangani perjanjian ini. Dari 195 negara yang menandatangani perjanjian tersebut, terdapat 146 negara yang telah menyetujui perjanjian tersebut. China, India, dan Amerika Serikat yang merupakan bagian dari negara-negara dengan emisi gas rumah kaca terbesar termasuk dari 146 negara yang turut menyetujui Paris Agreement (Zuhrufiyah \& Anggraeni, 2019).

\section{Pemanasan Global (Global Warming)}

Pemanasan global sudah diperbicangkan mulai tahun 1896, yaitu saat Arrhenius melakukan perhitungan kenaikan emisi karbondioksida di atmosfer meningkat dua kali lipat dan berpengaruh pada suhu permukaan bumi sebesar $4-6^{0} \mathrm{C}$ Nordhaus (dalam Sugiyono, 2006). Perhitungan Arrhenius diabaikan sampai tahun 1980 pada saat hadirnya bukti-bukti pendukung peningkatan jumlah konsentrasi gas rumah kaca pada atmosfer. Menurut Houghton et.al. dalam Sugiyono (2006), konsentrasi karbondioksida di atmosfer telah bertambah sebanyak 31\% dari awal revolusi industri hingga tahun 1998. Pembabatan hutan dan pembakaran bahan bakar fosil menjadi penyebab utama peningkatan konsentrasi gas rumah kaca.

Atmosfer memiliki segenap lapisan gas, tergolong di dalamnya gas rumah kaca dan awan, yang akan mengemisikan kembali setengah radiasi infra merah yang diterima di permukaan bumi. Akibat adanya lapisan tersebut maka panas yang terdapat di permukaan bumi dapat bertahan, proses ini disebut efek rumah kaca. Dampak jangka panjang yang akan terjadi akibat proses ini ialah terjadinya keseimbangan di antara radiasi yang keluar dengan radiasi yang masuk. Hal inilah yang mengakibatkan suhu di permukaan bumi mencapai angka tertentu (Sugiyono, 2006).

Selain itu, menurut penelitian Anggraeni (2015), terjadinya efek rumah kaca disebabkan oleh adanya peningkatan emisi gas-gas, di antaranya karbondioksida $\left(\mathrm{CO}_{2}\right)$, dinitrooksida $\left(\mathrm{N}_{2} \mathrm{O}\right)$, metana $\left(\mathrm{CH}_{4}\right)$, chlorofluorocarbons (CFC), dan lainnya, yang menyebabkan terperangkapnya energi matahari dalam atmosfer bumi. Beberapa gas tersebut timbul akibat adanya proses bisnis sehingga sudah seharusnya para pelaku bisnis bertanggung jawab dengan memberikan informasi terkait peran mereka dalam percepatan munculnya global warming.

\section{METODA PENELITIAN}

Penelitian ini merupakan sebuah penelitian kualitatif yang menggunakan metode penelitian kajian pustaka atau studi kepustakaan yang menurut Hardiansyah (2017) adalah sebuah metode yang berisi tentang teori-teori terkait dengan masalahmasalah penelitian. Adapun masalah pada penelitian ini ialah untuk mengetahui "Peran Akuntansi Karbon pada Perusahaan dalam Pencegahan Global Warming".

Pada metode penelitian kajian pustaka ini, penulis mengkaji konsep sekaligus teori yang diteliti bersumber pada literatur yang tersedia, yakni bersumber pada buku-buku teks, beberapa website resmi di internet, hasilhasil penelitian dalam bentuk skripsi, jurnaljurnal ilmiah yang dimuat dalam Google Scholar dan tak sedikit dari jurnal-jurnal tersebut telah terakreditasi SINTA, hal tersebut menandakan bahwa jurnal-jurnal tersebut telah melalui proses peer review 
sehingga dapat dipastikan sumber penelitian yang digunakan ialah sumber-sumber penelitian yang credible. Kajian pustaka memiliki tujuan utama untuk mengembangkan aspek manfaat praktis dan aspek teoritis. Sehingga dengan metode ini penulis dapat lebih mudah dalam menyelesaikan permasalahan yang diteliti.

Sifat penelitian yang penulis gunakan pada penelitian ini ialah penelitian deskriptif. Penelitian deskriptif dapat didefinisikan sebagai penelitian yang berfokus terhadap sistematis fakta yang didapatkan saat penelitian berlangsung.

\section{HASIL DAN PEMBAHASAN}

\section{Global Warming}

Global warming adalah kondisi terjadinya peningkatan temperatur suhu rata-rata, baik lautan, atmosfer, maupun daratan di muka bumi (Rusbiantoro, 2008). Global warming dapat dilihat dan dirasakan dengan terjadinya beberapa gejala, seperti peralihan musim yang tak menentu, meningkatnya intensitas hujan badai dan angin puting beliung, terjadinya banjir sekaligus kekeringan pada waktu yang bersamaan, timbulnya banyak wabah penyakit, serta memutihnya terumbu karang (Susanta and Sutjahjo, 2007). Pemanasan global sudah diperbicangkan mulai tahun 1896, yaitu saat Arrhenius melakukan perhitungan kenaikan emisi karbondioksida di atmosfer meningkat dua kali lipat dan berpengaruh pada temperatur permukaan bumi sebesar $4-6^{0} \mathrm{C}$ Nordhaus dalam Sugiyono (2006). Perhitungan Arrhenius diabaikan sampai tahun 1980 pada saat hadirnya bukti-bukti pendukung peningkatan jumlah konsentrasi gas rumah kaca pada atmosfer. Menurut Houghton et.al. dalam Sugiyono (2006), konsentrasi karbondioksida di atmosfer telah bertambah sebanyak 31\% dari awal revolusi industri hingga tahun 1998. Pembabatan hutan dan pembakaran bahan bakar fosil menjadi penyebab utama peningkatan konsentrasi gas rumah kaca yang menurut Susanta and Sutjahjo (2007) disebabkan oleh aktivitas manusia.

Atmosfer memiliki segenap lapisan gas, tergolong di dalamnya gas rumah kaca dan awan, yang akan mengemisikan kembali setengah radiasi infra merah yang diterima di permukaan bumi. Akibat adanya lapisan tersebut maka panas yang terdapat di permukaan bumi dapat bertahan, proses ini disebut efek rumah kaca. Dampak jangka panjang akibat proses ini ialah terjadinya keseimbangan di antara radiasi yang keluar dengan radiasi yang masuk (Sugiyono, 2006). Apabila terdapat banyak gas rumah kaca di atmosfer maka akan semakin kuat pula gas rumah kaca menjadi insulator yang membatasi panas dari pancaran sinar matahari pada permukaan bumi (Susanta and Sutjahjo, 2007). Hal inilah yang mengakibatkan suhu di permukaan bumi mencapai angka tertentu (Sugiyono, 2006).

Menurut penelitian Anggraeni (2015), penyebab terjadinya efek rumah kaca ialah adanya peningkatan gas emisi, di antaranya karbondioksida, dinitrooksida, metana, chlorofluorocarbons, dan lainnya, yang menyebabkan terperangkapnya energi matahari dalam atmosfer bumi. Beberapa gas tersebut timbul akibat proses bisnis sehingga sudah seharusnya para pelaku bisnis bertanggung jawab dengan memberikan informasi terkait peran mereka dalam percepatan munculnya global warming.

Berdasarkan penelitian Buchdahl et al. dalam Martusa (2009) global warming akan memberikan perubahan yang bersifat merusak bagi seluruh dunia. Pertama, dampak global warming bagi laut adalah akan memusnahkan berbagai makhluk hidup laut termasuk ikan yang merupakan salah satu sumber makanan untuk manusia. Selain itu, global warming juga akan menyebabkan cairnya es di Antartika dan Greenland yang mengakibatkan banjir atau tsunami di berbagai belahan dunia. Kedua, dampak global warming bagi pertanian ialah terjadinya perubahan curah hujan. Perubahan ini akan memusnahkan beberapa tanaman yang tidak mampu beradaptasi dalam kondisi tersebut. Hal ini akan mengakibatkan terjadinya kekurangan air dan makanan di berbagai belahan dunia. Perubahan yang ketiga terjadi pada hewan dan tumbuh-tumbuhan, beberapa hewan akan migrasi ke tempat yang lebih nyaman atau mungkin akan punah karena ketidakmampuannya dalam beradaptasi ketika terjadi global warming.

Perubahan selanjutnya adalah terjadi pada manusia, yaitu global warming akan menghasilkan polusi udara yang 
mengakibatkan timbulnya penyakit paru-paru dan risiko penyakit lainnya. Selain timbulnya penyakit, dampak lain global warming ialah terjadinya banjir yang dapat merusak kehidupan manusia. Global warming juga akan berdampak bagi sumber air, yaitu keringnya sumber air akibat terjadinya kekeringan yang berkepanjangan. Perubahan yang terakhir adalah bagi iklim, global warming akan membuat tingkat curah hujan berlebihan di beberapa tempat yang kemudian berpotensi menimbulkan banjir. Dengan adanya perubahan iklim juga akan mengakibatkan meningkatnya frekuensi terjadinya badai dan topan.

Menurut Utina (2009), terdapat beberapa cara untuk meminimalisasi dampak global warming, diantaranya dengan melakukan konservasi lingkungan yaitu penanaman pohon dan pemeliharaan pada lahan-lahan kritis, kemudian mengurangi pemakaian energi bahan bakar fosil dengan menggunakan energi alternatif, lalu melakukan efisiensi energi dan daur ulang, serta memberikan edukasi kepada masyarakat atas prinsip dimensi manusia dimana manusia harus memiliki kesadaran akan pentingnya kelestarian alam bagi hidup, penegakan hukum dan keteladanan untuk memberikan efek jera kepada pihak yang melanggar, pola pikir dan sikap manusia sebagai makhluk yang diberikan kemampuan akal sehat yang seharusnya mampu melihat kepentingan hidupnya yang memiliki keterkaitan dengan kehidupan makhluk lain serta kejadian prosesproses alam, keterpaduan setiap masyarakat untuk mendukung upaya pelestarian sumber daya alam dan lingkungan, dan etika lingkungan yang akan berguna apabila dilakukan dengan tindakan nyata pada kehidupan sehari-hari.

Salah satu upaya yang dapat dilaksanakan oleh perusahaan dalam rangka mengurangi dampak global warming yaitu dengan menciptakan pasar karbon. Hal ini dibuktikan dalam penelitian Callon dalam S \& Kartikasari (2009). Dalam hubungannya dengan global warming, paradigma lingkungan seperti efisiensi penggunaan air dan efisiensi penggunaan listrik akan memunculkan paradigma carbonomics, yang kemudian memunculkan paradigma carbon accounting pada lingkungan praktik akuntansi. Menurut Ratnatunga dalam S \& Kartikasari (2009), era carbonomics berkaitan dengan beberapa isu strategis dalam management accounting, seperti manajemen sumber daya manusia, kebijakan bisnis, evaluasi kerja, serta strategi pemasaran. Keterlibatan strategis pada bidang management accounting tersebut akan lebih bermakna untuk keterbukaan pelaporan transaksi dan emisi karbon, apabila pemerintah telah mengatur mekanisme transaksi dan batasan-batasan emisi secara tegas dalam standar akuntansi.

\section{Akuntansi Karbon di Indonesia}

Saat ini, perhatian dunia sedang tertuju pada sebuah topik global yakni isu lingkungan mengenai perubahan iklim dunia. Isu perubahan iklim sebagai mode baru dalam pelaporan lingkungan perusahaan telah membuka jalan mengenai sosial dan lingkungan untuk peneliti akuntansi. Hal tersebut melahirkan istilah baru, wacana, dan jargon pada literatur akuntansi, yaitu yang marak muncul adalah akuntansi karbon (Ahmad \& Hossain dalam Marlin, 2017). Menurut Taurisianti \& Kurniawati (2016) carbon accounting memiliki beberapa teori yang mendasari, salah satunya yaitu: akuntansi karbon adalah proses ketika organisasi menghitung dan melaporkan emisi gas rumah kaca mereka. Sehingga dapat disimpulkan bahwa akuntansi karbon adalah pencatatan laporan keuangan mengenai emiten karbon yang dihasilkan perusahaan. Dengan adanya pencatatan akuntansi karbon maka perusahaan dapat menghitung tingkat emisi karbon yang didapatkan dari proses pengukuran. Sehingga manajer perusahaan dapat menentukan strategi-strategi yang tepat untuk meminimalisasi jumlah emisi karbon yang dihasilkan pada periode selanjutnya serta melaporkannya kepada pemangku kepentingan perusahaan.

Carbon accounting semakin diperkuat dengan adanya penandatanganan Protokol Kyoto oleh segenap negara sebagai bentuk persetujuan internasional mengenai global warming. Protokol Kyoto diluncurkan pada tahun 1997 di Jepang yang didukung oleh Perserikatan Bangsa-Bangsa (PBB) (Janek Ratnatunga et al. dalam Marlin, 2017). 
Berdasarkan penelitian dari Pradita (2017), Protokol Kyoto dibentuk dengan tujuan untuk melindungi bumi dari peningkatan konsentrasi gas rumah kaca agar tidak memperburuk pola iklim bumi. Negaranegara yang menandatangani protokol ini berjanji bertanggung jawab dalam meminimalisasi jumlah emisi karbon yang akan mereka hasilkan nantinya (Taurisianti and Kurniawati, 2014).

Berdasarkan penelitian Setyaningrum (2015), Protokol Kyoto mengatur tiga mekanisme fleksibel, yaitu berupa:

1. Implementasi Bersama

Implementasi Bersama yaitu proses pengurangan emisi pada beberapa negara maju yang termasuk dalam Annex I, kemudian mereka dapat mengalihkan pengurangan emisi karbon dengan melakukan proyek kerjasama antarnegara dengan tujuan pengurangan emisi karbon.

2. Perdagangan Emisi

Perdagangan Emisi ialah sebuah proses jual-beli emisi antarnegara industri. Negara industri dengan gas emission rumah kacanya di bawah batas yang diperbolehkan dapat memasarkan jatah lebih emisi yang dimilikinya kepada negara-negara industri yang belum mampu menyelesaikan kewajibannya. Akan tetapi, jumlah gas emission rumah kaca yang dipasarkan dibatasi supaya pembeli emisi tetap menyelesaikan kewajibannya.

3. Mekanisme Pembangunan Bersih

Mekanisme Pembangunan Bersih ialah mekanisme yang diharapkan dapat membantu negara maju dalam menyelesaikan target pengurangan emisi karbon dan negara berkembang dapat mengimplementasikan program pembangunan berkelanjutan. Hal ini dapat dilakukan negara maju dengan cara berinvestasi pada program pengurangan emisi atau program lainnya yang memiliki potensi untuk meminimalisasi emisi atau menyerap gas rumah kaca pada negara berkembang. Kemudian, hasilnya akan dicatat sebagai pengurangan emisi karbon di negara maju yang berinvestasi.

Pada Negara Indonesia sendiri, mekanisme Protokol Kyoto dilaksanakan melalui penetapan Undang-Undang Nasional
Indonesia Nomor 32 Tahun 2009. UndangUndang ini ialah bentuk implementasi Protokol Kyoto yang berisi tentang perlindungan dan pengelolaan lingkungan hidup. Indonesia sebagai negara yang menandatangani dan mengesahkan Protokol Kyoto memiliki kewajiban untuk menerapkan isi dari protokol tersebut (Setyaningrum, 2015). Indonesia meratifikasi Protokol Kyoto dengan penerapan UU Nomor 17 Tahun 2004 sebagai upaya pelaksanaan pembangunan berkelanjutan sekaligus upaya pengurangan emisi gas rumah kaca secara global. Indonesia sebagai negara berkembang, tidak memiliki kewajiban untuk menurunkan tingkat emisi, tetapi keikutsertaan Indonesia sebagai negara berkembang sangat dibutuhkan dalam memenuhi tujuan UNFCCC.

Selain itu, Indonesia juga diharapkan dapat membantu peran negara maju dalam mendirikan beragam sektor pengurangan emisi serta meningkatkan tingkat penyerapan emisi karbon dengan investasi Irwhantoko dan Basuki dalam Iskandar (2019). Komitmen Indonesia dalam mengurangi emisi karbon semakin diperkuat dengan adanya Peraturan Presiden Nomor 61 Tahun 2011 dan Peraturan Presiden Nomor 71 Tahun 2011. Peraturan Presiden Nomor 61 Tahun 2011 berisikan peraturan terkait Perencanaan Aksi Nasional mengenai Pengurangan Emisi Gas Rumah Kaca, sedangkan Peraturan Presiden Nomor 71 Tahun 2011 membahas tentang penyelenggaraan inventarisasi GRK nasional (Iskandar, 2019). Tambahan pula, atas wujud kepedulian Indonesia terhadap permasalahan iklim global, Indonesia juga berkomitmen untuk menurunkan emisi karbon sebesar 26\% di tahun 2020, yakni kurang lebih sebesar 0,67 Gt (Jannah \& Muid dalam Marlin, 2017). Bahkan, target tersebut telah mengalami peningkatan menjadi $29 \%$ di tahun 2030 (Regional Kompas dalam Marlin, 2017).

Kemudian pada beberapa negara maju pun telah menerapkan carbon accounting, seperti pada tahun 2016, United Nations Climate Change Conference (UNFCCC) dalam Conference of the Parties 21 (COP 21) yang berdasarkan penelitian Seo, S. Niggol (2017) dilaksanakan di Paris menghasilkan perjanjian terbaru yaitu Paris Agreement. Paris Agreement ditetapkan dalam rangka menangani mitigasi, pembiayaan, dan adaptasi emisi gas rumah 
kaca yang dimulai pada tahun 2020. Tujuan dari perjanjian ini adalah untuk mencegah terjadinya peningkatan suhu global. Perjanjian ini mulai berlaku sejak tanggal 4 November 2016, kemudian pada tanggal 19 Mei 2017, sejumlah 195 negara bagian dan Uni Eropa ikut serta dalam menandatangani perjanjian ini. Dari 195 negara yang menandatangani perjanjian tersebut, terdapat 146 negara yang telah menyetujui perjanjian tersebut. China, India, dan Amerika Serikat yang merupakan bagian dari negara-negara dengan emisi gas rumah kaca terbesar termasuk dari 146 negara yang turut menyetujui Paris Agreement (Zuhrufiyah and Anggraeni, 2019).

Bersumber dari penelitian yang dilakukan oleh Setyaningrum (2015) didapatkan bukti kepedulian PBB terkait iklim dunia pada tahun 1990 bahwa secara resmi PBB mendirikan Intergovernmental Negotiating Comittee (INC) yaitu badan antar pemerintah yang melakukan perundingan menuju Konvensi Perubahan Iklim. Saat bulan Mei 1992, INC menyetujui kesepakatan terkait Kerangka Kerja Konvensi Perubahan Iklim PBB (UNFCCC). Kemudian, Konvensi Perubahan Iklim ini mulai disahkan pada Juni 1992 dalam KTT Bumi di Brazil, Indonesia termasuk salah satu negara yang menandatangani perjanjian Konvensi Perubahan Iklim bahkan Indonesia turut mengesahkan perjanjian tersebut melalui UU Nomor 6 Tahun 1994 (Pradita, 2017). Konvensi Perubahan Iklim ini menggolongkan negara-negara menjadi dua kelompok, yakni negara-negara maju digolongkan ke dalam kelompok Annex I, sedangkan negara-negara berkembang tergolong ke dalam kelompok non-Annex I. Walaupun digolongkan menjadi dua kelompok, baik negara-negara Annex I maupun negara-negara non-Annex I memiliki kewajiban yang sama yakni kewajiban dalam menyerahkan laporan yang dikenal dengan sebutan National Communication. Laporan National Communication ialah laporal perihal inventarisasi emisi gas rumah kaca serta kebijakan dan program perubahan iklim nasionalnya. Akan tetapi, sebagaimana yang dikatakan oleh Armely Meiviana dalam Setyaningrum (2015) bahwa negara nonAnnex I memiliki batas waktu yang lebih longgar dibandingkan negara Annex I dalam penyerahan laporan National Communication.

\section{Peran dan Manfaat Akuntansi Karbon terhadap Perubahan Iklim serta Lingkungan Sekitar}

Akuntansi karbon memiliki peran untuk mengatasi perubahan iklim yang mengakibatkan global warming. Peran akuntansi karbon tersebut menurut Dwijayanti (2011) dapat diimplementasikan untuk memberikan manfaat pada tiga kelompok, yaitu perusahaan, pemerintah, dan masyarakat. Peranan akuntansi karbon pada perusahaan sejalan dengan konsep CSR (Corporate Social Responsibility), yaitu dengan melakukan usaha untuk mengurangi tingkat emisi karbon. Apabila perusahaan melakukan berbagai usaha demi mengurangi emisi karbon yang dikeluarkan dari proses produksinya, maka dengan begitu perusahaan juga akan mengurangi polusi udara yang selanjutnya akan membantu menurunkan dampak global warming. Segala biaya yang dibayarkan dan berbagai usaha yang dilakukan oleh perusahaan berkaitan dengan konteks akuntansi karbon, dapat menjadi sebuah bentuk kepedulian yang diberikan perusahaan terhadap lingkungan sekitarnya. Bentuk kepedulian ini, memberikan manfaat untuk proses bisnis perusahaan. Beberapa manfaatnya adalah meningkatkan penjualan produk karena meningkatnya pandangan positif serta kepercayaan masyarakat atau konsumen terhadap perusahaan yang melakukan CSR, mendapatkan kepercayaan investor karena perusahaan yang memberikan laporan akuntansi karbon dianggap peduli terhadap lingkungan serta meningkatnya jumlah penjualan dan baiknya kinerja keuangan akibat dari diterapkannya CSR menjadi poin tambahan di mata investor sehingga mereka dengan yakin menanamkan modalnya pada perusahaan tersebut, selain itu bagi perusahaan yang menerapkan pelaporan akuntansi karbon sebagai bagian dari CSR juga dapat membantu perusahaan untuk mendapatkan kredit atau pinjaman dari kreditur, karena dengan banyaknya sumber permodalan yang didapatkan perusahaan dapat lebih mudah untuk mengembangkan usahanya, serta pelaporan akuntansi karbon 
dapat digunakan untuk mematuhi kewajiban dari Undang-Undang Nomor 40 Tahun 2007 mengenai tanggung jawab perusahaan terhadap sosial dan lingkungan.

Selain itu, menurut Kelvin et al., (2017) pelaporan emisi karbon berdampak signifikan dan positif terhadap kinerja operasional dan kinerja keuangan perusahaan. Pada kinerja operasional, pelaporan emisi karbon akan memotivasi manajer perusahaan untuk merestorasi alam yang akan membantu perusahaan dalam melakukan lebih banyak efisiensi, diantaranya menghemat energi listrik dan mengendalikan emisi dari pembakaran biomassa atau boiler sehingga dapat menurunkan biaya operasional serta meningkatkan keuntungan perusahaan. Dengan meningkatnya kinerja operasional perusahaan maka juga akan diiringi oleh peningkatan nilai aktiva perusahaan yang kemudian akan menciptakan kepercayaan dari para pemegang perusahaan sebagai perusahaan yang ramah lingkungan. Pengaruh terhadap kinerja keuangan dapat tercermin dari tercapainya keuntungan yang maksimal sebab ketertarikan konsumen hanya berfokus pada pemakaian produk yang diproduksi oleh perusahaan ramah lingkungan. Kinerja keuangan yang tinggi sebagai bentuk keuntungan yang maksimal menjadi gambaran bagi para investor bahwa masa depan kinerja keuangan perusahaan dapat dipertahankan.

Peranan akuntansi karbon pada pemerintah bisa dilihat dari kondisi wilayah Indonesia sebagai negara tropis yang memiliki karbon terestrial (hutan) yang besar, sehingga memiliki peluang untuk memangkas jumlah gas rumah kaca. Berdasakan mekanisme yang direkomendasikan Protokol Kyoto yaitu CDM (Clean Development Mechanism), yaitu kerjasama antara negara maju dan berkembang untuk mengurangi gas rumah kaca, sehingga negara maju akan memberikan dana kepada negara berkembang untuk mengelola hutan penyerap gas rumah kaca. Indonesia menjalin kerjasama dalam mengurangi tingkat emisi akibat degradasi dan deforestasi hutan (REDD/Reducing Emissions from Deforestation and forest Degradation). Indonesia bisa mendapatkan keuntungan yang banyak dari kerjasama program REDD ini karena Indonesia bisa mendapatkan bantuan dana yang diberikan negara maju yang menjalin kerjasama dengan Indonesia. Dana yang didapatkan tersebut dapat digunakan untuk membentuk sarana dan prasarana yang terdapat di luar Pulau Jawa dan juga sebagai usaha pemerintah Indonesia dalam menjalankan kesepakatan Protokol Kyoto. Selain itu, pemerintah juga seharusnya mulai mendesak industri atau perusahaan untuk mengimplementasikan enterprise carbon accounting (akuntansi karbon yang diimplementasikan di industri) dalam kegiatan usaha mereka. Hal ini tentu bermanfaat dalam mengurangi polusi udara di Indonesia yang juga merupakan salah satu bagian dari program pemerintah (Dwijayanti, 2011).

Berdasarkan penelitian Dwijayanti (2011), akuntansi karbon juga memiliki peran untuk menjaga kesehatan masyarakat karena diterapkannya akuntansi karbon pada industriindustri dapat mengurangi frekuensi pencemaran udara yang dapat membahayakan kesehatan masyarakat. Selain itu, dengan adanya penghutanan kembali (reboisasi) yang digunakan untuk menyerap gas rumah kaca, maka besarnya kemungkinan terjadinya bencana alam seperti banjir dan tanah longsor akan berkurang. Penerapan akuntansi karbon juga memiliki manfaat sebagai pembuka lapangan pekerjaan baru yang berkaitan dengan proses pengukuran emisi karbon, salah satu contohnya adalah akuntan dengan spesialisasi akuntansi karbon.

\section{Pengukuran, Pencatatan, Penyajian, dan Pengungkapan Akuntansi Karbon di Indonesia}

Bersumber dari penelitian yang dilakukan oleh Taurisianti \& Kurniawati (2016), dalam pengukuran akuntansi karbon terdapat sejumlah langkah yang harus dilakukan. Langkah pertama ialah melakukan pengukuran kandungan karbon terhadap setiap pohon berdasarkan kelompok usia. Selanjutnya, kemampuan setiap pohon dalam menyerap karbon akan ditetapkan sebagai dasar pengakuan besarnya kompetensi penyerapan karbon yang berkurang saat ditebangnya pohon tersebut. Setelah mengetahui besarnya kompetensi penyerapan karbon yang hilang, langkah selanjutnya adalah menetapkan asumsi terkait harga pasar perdagangan emisi. Hal tersebut dilakukan 
untuk mengubah tingkat potensi penyerapan karbon yang berkurang ke dalam satuan moneter. Langkah ketiga adalah melakukan penetapan asumsi kurs rupiah terhadap USD yang akan dipakai. Kemudian, langkah terakhir yaitu menetapkan usulan formula untuk perhitungan akuntansi karbon. Langkah-langkah tersebut dilakukan demi menghasilkan suatu nilai dalam satuan moneter rupiah yang kemudian diakui dan disajikan di dalam financial statement perusahaan.

Sesuai PSAK tahun 2010 nomor 19 dalam Taurisianti \& Kurniawati (2014) kemampuan penyerapan karbon suatu perusahaan diakui sebagai aset tak berwujud, lebih mendalamnya lagi dapat digolongkan ke dalam indefinitive intangible asset. Hal ini diakui berdasarkan kriteria definitive intagible asset yang tercatat pada PSAK tahun 2010 nomor 19 dalam Taurisianti \& Kurniawati (2014) yaitu aset yang harus diamortisasi berdasarkan masa manfaatnya dan dilakukan pengujian terhadap nilai jika terdapat indikasi penurunan nilai. Kriteria-kriteria tersebut dapat terwujud oleh daya serap yang dimiliki pohon atas karbon. Pencatatan pendapatan dari surplus potensi serap karbon dicatat sebagai pendapatan non operasional berdasarkan PSAK 23. Pencatatan estimasi kemampuan penghasil emiten karbon yang diatur dalam PSAK 57 dicatat sebagai kewajiban diestimasi atau provisi. Berdasarkan PSAK 32, pencatatan beban terkait defisit kemampuan serap karbon dicatat sebagai beban non operasional (Taurisianti and Kurniawati, 2014).

Tabel 1.Format Pelaporan Akuntansi Karbon

\section{PT ABC}

Laporan Akuntansi Karbon Perusahaan

Untuk tahun yang berakhir tanggal 31 Desember 2020

\begin{tabular}{|c|c|c|}
\hline Aktivitas & Biaya Akuntansi Karbon & $\begin{array}{l}\text { Presentase dibandingkan } \\
\text { Total Biaya Operasional }\end{array}$ \\
\hline \multicolumn{3}{|l|}{ Biaya Pencegahan: } \\
\hline Desain produk & $\ldots .$. & \\
\hline Pelatihan karyawan & $\ldots .$. & \\
\hline Pemilihan peralatan & $\mathrm{Rp} \ldots . .$. & .....\% \\
\hline \multicolumn{3}{|l|}{ Biaya Pendeteksian: } \\
\hline Penetapan ukuran & $\ldots .$. & \\
\hline Inspeksi & $\ldots \ldots$ & $\ldots . . \%$ \\
\hline \multicolumn{3}{|l|}{ Biaya Kegagalan Internal: } \\
\hline $\begin{array}{l}\text { Pemeliharaan peralatan untuk } \\
\text { mengatasi polusi }\end{array}$ & ..... & \\
\hline $\begin{array}{l}\text { Pengoperasian peralatan } \\
\text { untuk mengatasi polusi }\end{array}$ & $\ldots \ldots$ & $\ldots . . . \%$ \\
\hline Biaya Kegagalan Eksternal: & & \\
\hline $\begin{array}{l}\text { Klaim kesehatan akibat udara } \\
\text { yang tercemar }\end{array}$ & $\operatorname{Rp} \stackrel{\ldots \ldots}{\cdots}$ & $\frac{\ldots . \% \%}{\ldots \ldots \%}$ \\
\hline
\end{tabular}

Sumber: Hansen and Mowen (2006, dalam Dwijayanti, 2011)

Menurut penelitian Taurisianti \& Kurniawati (2016), yang berdasar pada PSAK 57 , penyajian dan pengungkapan provisi disajikan di sisi kredit dalam financial statement. Kemudian, diatur pula bahwa aset kontijensi tidak dimasukkan dalam financial statement. Aset tidak berwujud menurut PSAK 19 penyajian dan pengungkapannya di posisi debit dalam laporan posisi keuangan. Penyajian dan pengungkapan pendapatan tersajikan sebagai pendapatan non operasional dalam perhitungan laba rugi bersih pada tahun berjalan berdasarkan PSAK 23. Menurut PSAK 32, beban disajikan menjadi beban non operasional dalam perhitungan laba rugi bersih pada tahun berjalan. 


\section{Pelaporan Akuntansi Karbon}

Menurut Dwijayanti (2011), Perusahaan yang secara aktif menerapkan akuntansi karbon akan membuat pelaporan akuntansi karbon sebagai komponen dari biaya perusahaan sehingga akan diperoleh secara signifikan peran perusahaan dalam pencegahan polusi industri atau udara dari operasi bisnisnya. Pelaporan akuntansi karbon dapat digabungkan dengan laporan akuntansi lingkungan oleh perusahaan.

Terdapat empat kategori biaya yang dapat dimasukkan dalam pelaporan akuntansi karbon, yaitu:

a. Biaya pencegahan

Biaya pencegahan ialah biaya yang dibayarkan oleh perusahaan dalam melakukan pencegahan terhadap polusi udara.

b. Biaya pendeteksian

Biaya pendeteksian yaitu biaya yang dibayarkan oleh perusahaan dalam melakukan penemuan, pengurangan dan pendeteksian banyaknya jumlah polusi udara yang dikeluarkan.

c. Biaya kegagalan internal

Biaya kegagalan internal merupakan biaya yang dibayarkan apabila polusi udara yang dikeluarkan oleh perusahaan telah melebihi batas, namun belum berdampak secara eksternal.

d. Biaya kegagalan eksternal

Biaya kegagalan ekternal yaitu biaya yang dibayarkan apabila polusi udara yang dikeluarkan oleh perusahaan telah memberikan dampak secara luas kepada lingkungan, masyarakat sekitar, serta pihak-pihak eksternal lainnya.

Pelaporan akuntansi karbon ini dapat dikategorikan sebagai voluntary disclosure perusahaan dan merupakan bagian dari CSR perusahaan. Dengan adanya pelaporan ini, pemangku kepentingan dapat melihat andil perusahaan dalam menurunkan jumlah gas rumah kaca sekaligus sebagai bentuk rasa peduli perusahaan kepada lingkungan (Dwijayanti, 2011).

\section{Perkembangan Regulasi di Indonesia}

Sebagai tindak lanjut komitmen global untuk mengurangi dampak perubahan iklim, Indonesia mengesahkan Undang-Undang Nomor 6 Tahun 1994 tentang pengesahan Konvensi Kerangka Kerja Perserikatan Bangsa-Bangsa Mengenai Perubahan Iklim. Pada tahun 2004, sebagai respon komitmen global dalam Protokol Kyoto periode pertama, pemerintah Indonesia mengesahkan UndangUndang Nomor 17 Tahun 2004 tentang Pengesahan Protokol Kyoto atas Konvensi Kerangka Kerja Perserikatan Bangsa-Bangsa Tentang Perubahan Iklim.

Komitmen pemerintah Indonesia untuk mengurangi emisi karbon GRK juga terlihat dari keseriusan pemerintah pada tahun 2009 pasca pertemuan G20. Presiden Susilo Bambang Yudhoyono pada saat itu mengeluarkan Perpres Nomor 61 Tentang Rencana Aksi Nasional Penurunan Emisi Gas Rumah Kaca (RAN GRK). Peraturan ini dianggap memiliki hubungan erat dengan implementasi keuangan berkelanjutan di Indonesia. Perpres tersebut kemudian ditindak lanjuti kembali dengan Peraturan Presiden Nomor 71 Tahun 2011 tentang Penyelenggaraan Inventarisasi GRK Nasional. Peraturan ini lebih menekankan pada penyelenggaraan teknis untuk informasi simpanan karbon pada tingkat nasional, provinsi, dan kabupaten/kota di Indonesia. Tujuan dari Peraturan Presiden ini yaitu sebagai payung hukum untuk penyediaan informasi tingkat karbon, status, kecenderungan emisi, dan serapan GRK di tingkat nasional maupun pemerintah daerah.

Pada tahun 2012, KLHRI menyusun dan menerbitkan 4 buku pedoman penyelenggaraan inventarisasi GRK nasional, yaitu sebagai berikut

a. Buku I: Pedoman Umum

b. Buku II Volum I: Metodologi Perhitungan Tingkat Emisi Gas Rumah Kaca Kegiatan Pengadaan dan Penggunaan Energi

c. Buku II Volum II : Metodologi Perhitungan Tingkat Emisi Gas Rumah Kaca - Proses Industri dan Penggunaan Produk

d. Buku II Volum III : Metodologi Perhitungan Tingkat Emisi Gas Rumah Kaca - Pertanian Kehutanan dan Penggunaan Lahan Lainnya. 


\section{SIMPULAN DAN SARAN}

\section{Simpulan}

Pada penelitian ini, penulis menyimpulkan bahwa peran akuntansi karbon pada perusahaan dalam pencegahan global warming adalah dengan diterapkannya akuntansi karbon pada banyak perusahaan atau industri, maka akan menambah banyaknya lahan penyerapan gas rumah kaca. Dengan banyaknya lahan penyerapan gas rumah kaca seperti hutan, maka akan semakin banyak pula karbondioksida yang diserap sehingga dapat mengurangi global warming. Dengan berkurangnya tingkat global waming, maka bencana alam seperti mencairnya es di wilayah kutub, banjir, badai, dan topan dapat diminimalisasi frekuensi terjadinya. Pelaporan akuntansi karbon juga membantu perusahaan untuk merencanakan strategistrategi yang tepat dalam meminimalisasi banyaknya emisi karbon yang akan dikeluarkan pada periode berikutnya. Dengan begitu, akuntansi karbon akan membantu

\section{DAFTAR REFERENSI}

Andriyani, S. (2010) 'Akuntansi Karbon Sebagai Perspective Baru dalam Perkembangan Akuntansi Lingkungan', Widya Mandala Catholic University Surabaya, pp. 1-32.

Anggraeni, D. Y. (2015) 'Pengungkapan Emisi Gas Rumah Kaca, Kinerja Lingkungan, dan Nilai Perusahaan (Greenhouse Gas Emission Disclosure, Environmental Performance, and Firm Value)', Jurnal Akuntansi dan Keuangan Indonesia, 12(2), pp. 188-209.

Dwijayanti, P. (2011) 'Manfaat Penerapan Carbon Accounting Di Indonesia', Jurnal Akuntansi Kontemporer, 3(1), pp. 79-92.

Hardiansyah, R. (2017) Relevensi Konsep Ulul Albab dalam Q.S Ali Imron 190-195 dengan Tujuan Pendidikan Islam. UIN Raden Intan Lampung.

Iskandar, A. Y. (2019) Pengaruh Ukuran Perusahaan, Leverage, dan Profitabilitas terhadap Carbon Emission Disclosure, Universitas Sriwijaya. doi: 10.22201/fq.18708404e.2004.3.66178

Kelvin, C., Daromes, F. E. and Ng, S. (2017) 'Pengungkapan emisi karbon sebagai mekanisme peningkatan kinerja untuk global warming untuk tidak semakin memburuk atau bahkan dapat menurunkan tingkat global warming yang terjadi.

\section{Saran}

Pada penelitian selanjutnya, penulis menyarankan untuk menggunakan lebih banyak referensi dari jurnal nasional maupun internasional yang sudah dipastikan kebenarannya. Kemudian, penulis juga menyarankan kepada peneliti selanjutnya untuk memperkuat fakta penelitiannya dengan melakukan observasi langsung. Lalu, teruntuk perusahaan atau industri yang mengeluarkan emisi karbon dalam kegiatan usahanya disarankan untuk dapat lebih peduli terhadap lingkungan dengan menerapkan akuntansi karbon pada perusahaannya. Masyarakat pun disarankan untuk ikut serta dalam menjaga iklim bumi dengan cara tidak menebang pohon sembarangan, menanam pepohonan, dan menghemat energi.

menciptakan nilai perusahaan', unisbank.ac.id, 6(1), pp. 1-18. Available at:

https://www.unisbank.ac.id/ojs/index.php /fe9/article/view/5948 (Accessed: 13 January 2021).

Marlin, S. (2017) 'Analisis Pengungkapan Emisi Karbon pada PT Perusahaan Gas Negara (PGN) Tbk dan PT Astra Agro Lestari Tbk Tahun 2013-2015', Jurnal Akuntansi, 5(1), pp. 1-16.

Martusa, R. (2009) 'Peranan Environmental Accounting terhadap Global Warming', Jurnal Akuntansi, 1(2), pp. 164-179.

PPID (2020) Hutan dan Deforestasi Indonesia Tahun 2019.

Pradita, S. (2017) 'Implikasi Ratifikasi Protokol Kyoto terhadap Politik Internasional dan Domestik Indonesia', Jurnal Analisis Hubungan Internasional, 6(1), pp. 181-191.

Rusbiantoro, D. (2008) Global warming for beginner: pengantar komprehensif tentang pemanasan global. Yogyakarta: Panembahan Yogyakarta.

S, M. J. and Kartikasari, L. (2009) '2009(B)', pp. 1-23.

Seo, S. N. (2017) 'Beyond the Paris Agreement: Climate change policy 
negotiations and future directions',

Regional Science Policy and Practice, 9(2), pp. 121-140. doi:

10.1111/rsp3.12090.

Setyaningrum, W. (2015) 'Analisis Yuridis

Implementasi Protokol Kyoto di

Indonesia Sebagai Negara Berkembang', Jurnal Komunikasi Hukum (JKH), 1(2), pp. 185-198. doi:

$10.23887 /$ jkh.v1i2.6108.

Sugiyono, A. (2006) 'Penanggulangan

Pemanasan Global di Sektor Pengguna

Energi', Jurnal Sains \& Teknologi

Modifikasi Cuaca, 7(2), pp. 16-19.

Susanta, G. and Sutjahjo, H. (2007) Akankah

Indonesia tenggelam akibat pemanasan global? Penebarplus.
Taurisianti, M. M. and Kurniawati, E. P. (2014) 'Perlakuan Akuntansi Karbon di Indonesia', Jurnal Ekonomi dan Bisnis, 17(2), pp. 81-105. doi: 10.24914/jeb.v17i2.273.

Utina, R. (2009) 'Pemanasan global: dampak dan upaya meminimalisasinya', academia.edu.

What is the Kyoto Protocol? (2012) United Nations Climate Change.

Zuhrufiyah, D. \& and Anggraeni, D. Y. (2019) 'Pengungkapan Emisi Karbon dan Nilai Perusahaan (Studi Kasus pada Perusahaan di Kawasan Asia Tenggara)', Jurnal Manajemen Teknologi, 18(2), pp. 80-105. doi: 10.12695/jmt.2019.18.2.1.

\section{Copyrights}

Copyright for this article is retained by the author(s), with first publication rights granted to the journal.

This is an open-access article distributed under the terms and conditions of the Creative Commons Attribution license (http://creativecommons.org/licenses/by/4.0/). 